\title{
EDITORIAL
}

\section{Nutritionists as guinea-pigs}

The British Journal of Nutrition prides itself on high statistical standards. It is one of the few journals which has specialist Statistical Editors amongst its Editorial Board. But every now and then a paper comes along which just does not fit into the normal pattern, and to which normal statistical standards cannot be applied. This issue of the Journal includes such a paper. The article by Stroud et al. (1996) describes studies made during the first author's crossing of Antarctica in 1992-3 with his companion, Ranulph Fiennes, a journey described from a more personal point of view in Mike Stroud's book, Shadows on the Wasteland (Stroud, 1993). This was not just an expedition made in the long tradition of man pitting himself against the elements, but was also a scientific study of human responses to sustained heavy exercise under very adverse environmental conditions. All those who were involved in reviewing the paper submitted by Dr Stroud and his co-authors agreed that in this instance it was unreasonable to complain to the authors that $n 2$ is insufficient, and that we would be prepared to consider a revised paper only if the numbers could be increased: there are important and unrepeatable data here which will be of interest to many researchers.

Mike Stroud's study of his own responses to diet, exercise and extreme environmental conditions is one of a long line of experiments in which the experimenter has used him- or herself as guinea-pig. Sometimes, because of the nature of the investigation, the number of subjects is of necessity small. Thus, Sir Charles Martin described studies of his own metabolism including daily measurements of resting metabolic rate and rectal temperature during a sea voyage to Australia (Martin, 1930). Although he tried also to study a medical friend who accompanied him, he found his friend's metabolism to be much more variable, perhaps, Martin suggested, because 'I was not able to control his food supply and habits as I was my own'. The topic of self-experimentation has been discussed from time to time in the medical literature (Altman, 1972; Forrester, 1990; van Everdingen \& Cohen, 1990). Medical and physiological experimenters have given themselves diseases and poisons (sometimes with fatal results), tested the effects of drugs including LSD, and one catheterized his own heart (to prove that the procedure was not invariably lethal) (Altman, 1972). van Everdingen \& Cohen (1990) describe one person who published twenty papers with himself as the only subject. These exploits and a number of others are described in the book Who Goes First? by Altman (1987).

The tradition of self-experimentation is strong amongst nutritionists, and some of their stories were reviewed recently by Dr Elsie Widdowson (herself a good example of a selfexperimenter) (Widdowson, 1993). Amongst the nutritional self-experimenters described by Dr Widdowson were a number of past and present members of the Nutrition Society, including Dr Robert McCance, Dr Hugh Sinclair and Dr Widdowson herself. I do not intend to repeat Dr Widdowson's stories here, but will add a few more which may be of interest, again concerning members of the Nutrition Society and their contemporaries.

Professor John Garrow may be surprised to find himself amongst my list of nutritional self-experimenters, but in the second edition of his book Energy Balance and Obesity in Man (Garrow, 1978) he reported studies of his own body weight in which he tested the idea that some people, himself included, had a natural 'set-point'. After deliberately losing $7 \mathrm{~kg}$ 
in weight for an experiment on protein turnover, he was weighed by an assistant who did not pass on any information, expecting to return to his initial weight. However, over a period of 7 months he not only regained his initial weight, but overshot to the extent that the tightness of his clothes provided an external cue and he 'broke' the blindness of the weighing. The findings were reported to the Nutrition Society (Garrow \& Stalley, 1977). Garrow encouraged other nutritionists to join the SEOOAH (the Society for Enquiry into One's Own Alimentary Habits), and I for one was strongly influenced in my further research by John Garrow's findings and his writings on this subject.

John Garrow in fact informs me that he was taught the advantages of selfexperimentation whilst working for another prominent member of the Nutrition Society, Professor John Waterlow, who led the Tropical Metabolism Research Unit (TMRU) in Jamaica in the 1950s and 1960s. In making enquiries for this editorial, I have found John Waterlow and his many colleagues to be a mine of information on the topic of nutritional self-experimentation. For instance, John Waterlow himself has described to me studies on the causes of mountain sickness in which he made himself potassium-deficient before climbing to high altitude in the Andes, which led to him becoming comatose and grossly oedematous, only recovering after returning to lower altitude with a supply of potassium tablets. There is also a story about a self-administered intravenous infusion of lysine to measure protein turnover, in which the rather acidic lysine solution had not been neutralized as intended, resulting in a nasty phlebitis. A paper published from the Waterlow group in those days (Garrow \& Waterlow, 1959) has a tell-tale clue in describing "A normal adult male (J.S.G.) [who] was injected once with iodinated albumin and three times with Evans blue'. John Garrow tells me that 'this is the sort of study you really have to do yourself: by the end my skin was quite a deep blue!'. Joe Millward, now a Professor of Nutrition but in those days a young member of the same team, tells me that the best slides of skeletal muscle ultrastructure which he uses in his teaching were prepared from a biopsy of his own quadriceps, taken in response to a plea for control material while he was visiting the TMRU one year. Later, Joe Millward, together with his colleague Mike Rennie, working with Professor Richard Edwards at the Rayne Institute in London, carried out a series of studies of muscle protein turnover and its response to exercise which involved them in treadmill exercise, bicycling and running around Regent's Park before muscle biopsies.

The extensive use of the technique of muscle biopsy for studying muscle metabolism and its responses to exercise and nutrition derives from pioneering studies in the 1960 s and 1970 s by Jonas Bergström and Eric Hultman at the Karolinska Institute in Stockholm (Bergström \& Hultman, 1972). In those studies they used Bergström's muscle biopsy needle, together with Hultman's technique for measurement of small amounts of aldosaccharides, to determine the changes in muscle glycogen occurring with exercise and with pre- and post-exercise nutrition. I have learned only recently that the two subjects who appear regularly in many of those early papers were indeed Bergström and Hultman themselves.

My own immodest contribution to these anecdotes is the following. For the past few years my colleagues and $I$ in Oxford have been exploring the metabolism of human adipose tissue in vivo, and its responses to feeding and fasting (Frayn, 1992). The technique involves a somewhat tricky cannulation of a small vein draining the subcutaneous abdominal adipose tissue. We have realized over the years that this technique might never have been developed had we not carried out most of our initial probings on a subject who just happens by a quirk of anatomy to have a rather larger than average vein, now known locally as the Great Vein of Frayn (GVF). Curiously, a colleague recently recruited my own son (a hardup student) for such a study, and we were all surprised to find that the GVF is an inherited structure. 
It would be misleading to give the impression that nutritional self-experimentation is confined to this side of the Atlantic. Many Americans have made important contributions to nutritional science in this way, particularly with respect to the symptoms and aetiologies of vitamin deficiencies, and their stories are grippingly told by Altman (1987) and by Widdowson (1993).

No doubt the tradition of self-experimentation will continue amongst nutritionists and other experimental scientists. Although modern ethical standards and the strict regulation of human experimentation by ethical committees might have prevented some of these pioneering studies from being carried out, all of us who carry out invasive studies on humans know that the easiest person to persuade to be the first subject for a new procedure is the person who thought of it. In fact there may even be a good statistical basis for selfexperimentation. Law (1993) points out that in properly designed dietary intervention trials 'the necessary sample size... can be so small... that a group of investigators could use themselves as subjects. They might study alcohol for example, taking in random order no alcohol for a month, two or three units of alcohol per day for a month, and perhaps (in the cause of science!) five or six units of alcohol per day for a month .... Such a trial would be more useful than a very much larger observational study'. Forrester (1990) summarized other benefits of using oneself as an experimental subject: "There is convenience and economy - no one else to be organized, briefed, and even reimbursed. The cooperation is inevitably complete.... There are no ethical problems, or at any rate fewer problems. There is also a special variety of excitement, familiar to explorers of other kinds also'. That seems to bring us back to Mike Stroud and Ranulph Fiennes.

Do remember that the Journal is pleased to consider publishing correspondence relating to this or other matters. Perhaps this will open up the flood gates to anecdotes about nutritional self-experimentation.

I thank Professor John Waterlow for his helpful comments.

K. N. FraYN

\section{REFERENCES}

Altman, L. K. (1972). Auto-experimentation. An unappreciated tradition in medical science. New England Journal of Medicine 286, 346-352.

Altman, L. K. (1987). Who Goes First? New York: Random House.

Bergström, J. \& Hultman, E. (1972). Nutrition for maximal sports performance. Journal of the American Medical Association 221, 999-1006.

Forrester, J. M. (1990). Using oneself as one's only experimental subject. Lancet 336, 798-799.

Frayn, K. N. (1992). Studies of human adipose tissue in vivo. In Energy Metabolism: Tissue Determinants and Cellular Corollaries, pp. 267-295 [J. M. Kinney and H. N. Tucker, editors]. New York: Raven Press.

Garrow, J. S. (1978). Energy Balance and Obesity in Man, 2nd ed. Amsterdam: Elsevier/North Holland.

Garrow, J. S. \& Stalley, S. F. (1977). Cognitive thresholds and human body weight. Proceedings of the Nutrition Society 36, 18A.

Garrow, J. S. \& Waterlow, J. C. (1959). Observations on Evans blue dye as a tracer for human plasma albumin. Clinical Science 18, 35-43.

Law, M. R. (1993). Small trials rather than large observational studies in nutritional epidemiology, European Journal of Clinical Nutrition 47, 229-231.

Martin, C. J. (1930). Thermal adjustment of man and animals to external conditions. Lancet ii, 617-620.

Stroud, M. (1993). Shadows on the Wasteland. London: Jonathan Cape.

Stroud, M. A., Jackson, A. A. \& Waterlow, J. C. (1996). Protein turnover rates of two human subjects during an unassisted crossing of Antarctica. British Journal of Nutrition 76, 165-174.

van Everdingen, J. J. E. \& Cohen, A. F. (1990). Self-experimentation by doctors. Lancet 336, 1448.

Widdowson, E. M. (1993). Self-experimentation in nutrition research. Nutrition Research Reviews 6, 1-17. 